\title{
GOVERNANCE AND REGULATION AS AN INDISPENSABLE CONDITION FOR DEVELOPING THE POTENTIAL OF RURAL AREAS
}

\author{
Kateryna Mazur ${ }^{1}$, Inna Tomashuk ${ }^{2}$
}

\begin{abstract}
The subject of the study is the rural territories and settlements of the country, which are influenced by the conflicting processes of reforming the economic basis of their development, which increases the uncertainty and causes the emergence of social risks in terms of organization of economic activity and obtaining the required level of labor income and, accordingly, the level and quality of life. The current transformational changes in rural areas, amid the processes of decentralization of the current management system, create new conditions that are more or less conducive to the successful organization of rural residents' livelihoods. The urgent task of today is to study the practical problem of the effective development of rural territories, the insufficiency of its development and the complex tasks of revitalization of rural territories of their resource potential in the context of intra-regional features of rural development, which is the basis for carrying out scientific research in accordance with these topics. The purpose of the study is to explore ways to solve problems of regional development, especially rural development, which has never been neglected by economic science, since sustainable development of the country and its regions is impossible without the social revival of the village. Also, a comprehensive theoretical and practical study of issues of management and state regulation of rural development, in particular, the substantiation of socio-economic and environmental problems of the development of the Ukrainian village, the isolation of rural areas, the formation of organizational and economic mechanism of state support for their development and implementation of modern state agricultural policy. Methodology. The problematic of the development of the potential of rural territories is based on the use of multifaceted scientific methods of knowledge of phenomena and processes. Application of statistical methodology in the process of analyzing the dynamics and tendencies of rural development, the effective functioning of agriculture, which is the basis for the study of problems of rural development in general. Economic and statistical research is based on specific techniques, their totality forms the methodology of statistics (methods of mass observations, groupings, generalizations, time series, index method, etc.). Results. In the conditions of formation of market relations in rural areas, especially in the period of economic instability in the country, the study of preconditions for ensuring balanced potential of rural development on the basis of internally oriented motivational factors, justification of priority types of economic activity of rural territories of the region with observance of ecological requirements becomes extremely relevant. One of the main areas to reform the regional development management mechanism is the development of local initiative. The practical implementation is to use the method of delegation of authority as one way of establishing the competence of local public authorities, which is an important part of the decentralization of the executive power, and is of great importance for all processes of the rule of law and, in particular, for improving the efficiency of the local government system. public authority. The Institute of Delegation of Authority in the current context is important for the functioning of public authority in rural areas. In addition, the introduction of a programmatic targeting method in the budgetary process of rural development will help to ensure transparency of the budgetary process, which will clearly define the goals and objectives for which the budgetary resources of the region are spent, which in turn will increase the level of control over the results of implementation of budgetary programs. This approach will improve the quality of fiscal policy-making, the efficiency of distribution and the
\end{abstract}

\footnotetext{
Corresponding author:

${ }^{1}$ Vinnytsia National Agrarian University, Ukraine.

E-mail: kv_mazur@ukr.net

ORCID: https://orcid.org/0000-0002-1137-3422

${ }^{2}$ Vinnytsia National Agrarian University, Ukraine.

E-mail: tomashuk.inna@ukr.net

ORCID: https://orcid.org/0000-0001-6847-3136
} 
use of budgetary resources in rural areas. Value/originality. State policy in Ukraine on regulating the potential of land relations should be aimed at solving the organizational and legal problems that have accumulated in recent years and to address the social negatives of land transformation in the countryside.

Key words: rural areas, development management, reform, state support, decentralization, modernization.

JEL Classification: P25, Q14, R11, R58

\section{Introduction}

Deepening European integration processes require the formation of a new model of rural development, adapted to world standards, which enhances its role in the socio-economic development of Ukraine and its regions. Thus, the topic discussed in the article, namely governance and state regulation as an indispensable condition for developing the potential of rural territories, is quite relevant.

The purpose of the article is to study the existing problematic issues related to the management and state regulation of the development of the resource potential of rural territories and to identify the main directions of its improvement. The purpose of the study is to carry out a comprehensive analysis of the current state and problems of managing the resource potential of rural areas. It is necessary to justify the criteria for optimizing their management, to determine the strategic priorities of their development. Dialectical method, scientific abstraction, induction and deduction, historical and logical method, systematic, monographic, analytical and other research methods are used to study the theoretical and methodological bases of managing the development of potential of rural areas. The potential of development of rural territories of Ukraine, as well as the state as a whole, can only be discovered and realized if an effective system of public administration is formed. Thus, the scientific novelty of the article is to improve public administration in the context of studying the current state of rural development, to increase the efficiency of utilization of the resource potential of rural areas and the economy of Ukraine as a whole. In this context, decentralization of power as a component of state regional development policy is one of the defining reforms agenda in Ukraine. It has created the groundwork for rooting institutional change, for improving the quality of life of citizens, and for the continuation of sectoral reforms. Thanks to the creation of a new system of power distribution between central and local authorities in Ukraine, a new system of relations between different branches of power and a new equilibrium of checks and balances are in fact being formed today.

\section{Classification of rural development facilities and their modernization}

In a market environment, the problem of priority rural development, including the development of rural territories, becomes particularly relevant, as it implements the socio-economic interests of different age and sex groups, relations between society and human beings, satisfies their material and spiritual needs, creates adequate living conditions (Table 1).

Table 1

Classification of rural areas

\begin{tabular}{|c|c|c|}
\hline & Name & Characteristic \\
\hline I & Natural & $\begin{array}{l}\text { - picturesque landscape; } \\
\text { - availability and opportunities for the use of } \\
\text { natural resources; } \\
\text { - low degradation of the natural appearance of } \\
\text { the territory. }\end{array}$ \\
\hline II & Geographic & $\begin{array}{l}\text { - proximity to highways; } \\
\text { - proximity to cities and business centers. }\end{array}$ \\
\hline III & Social & $\begin{array}{l}\text { - development of social capital; } \\
\text { - social stability and cohesion; } \\
\text { - community activity; } \\
\text { - self-government. }\end{array}$ \\
\hline IV & Economic & $\begin{array}{l}\text { - balance of the local labor market; } \\
\text { - availability of business prospects; } \\
\text { - cost of living; } \\
\text { - development of the service infrastructure. }\end{array}$ \\
\hline V & Ecological & $\begin{array}{l}\text { - unique natural environment; } \\
\text { - nature reserves; } \\
\text { - national natural and regional landscape } \\
\text { parks. }\end{array}$ \\
\hline VI & Cultural & $\begin{array}{l}\text { - endogenous cultural specificity; } \\
\text { - lifestyle; } \\
\text { - development of local crafts; } \\
\text { - historical value of the territory. }\end{array}$ \\
\hline
\end{tabular}

Source: generated by the authors according to the study

The beginning of the XXI centuryis characterized by the need to implement a strategy and policy of rational structural change and modernization of the Ukrainian economy, taking into account the strengthening of endogenous factors that affect the development of rural areas. This strategy should be based on accelerated development of investment and innovation potential as an internal source of qualitative development, provided that a reasonable level of openness of the economy is determined. At the same time, internal resources are shifted to competitive activities that provide relatively stable growth effect while strengthening the position of the national producer (Figure 1) (Bobrovska, 2014; Hazuda, Erfan, \& Hazuda, 2015). 


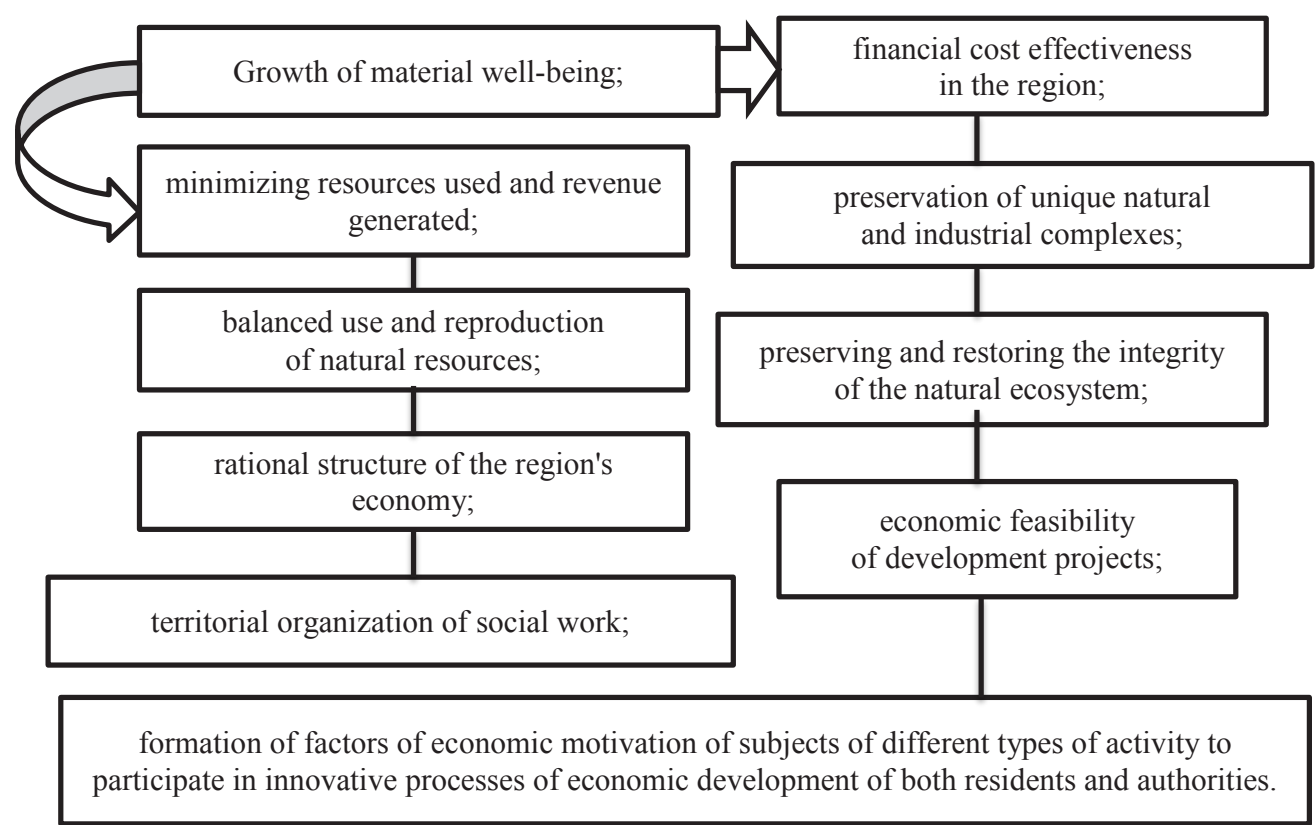

Figure 1. Basic principles of development of own economic policy of development of regional rural territories

Source: generated by the authors according to the study

\section{Information and analytical activity of rural development}

Information and analytical activity, as a special area of information activity related to the detection, processing, storage and dissemination of information mainly in the field of management, political and economic activity, consists of information search and analytical processing of information (Table 2) (Hazuda, Erfan, Hazuda, 2015; Zinchuk, Kutsmus, 2012).

Emphasizing attention to the particularities of certain rural areas, economist scholars emphasize their uniqueness and outline their fundamental features (Figure 2) (Hazuda, Erfan, \& Hazuda, 2015; Zaiats, 2017).

\section{Main measures for social adaptation of rural areas}

For social adaptation of rural areas, a number of measures should be envisaged (Figure 3) (Hazuda, Erfan, \& Hazuda, 2015; Smutchak, 2019).

The need for state financial regulation of rural development is due to the fact that for any type of economic system, the main purpose of the state is to provide financial resources to those needs that cannot be met through a market mechanism (Zaiats, 2017; Chuhunov, Pavelko, Kanieva, Mazaraki, 2015). In this context, the whole set of rural competitiveness factors depending on the preferences (demand) of the

Table 2

Stages of information retrieval and analytical processing of information to improve the utilization of rural resource potential

\begin{tabular}{|c|c|}
\hline Information search & Analytical processing of information \\
\hline $\begin{array}{l}\text { - Data collection and analysis, search and evaluation of } \\
\text { information using information and telecommunication } \\
\text { technologies and Internet capabilities; } \\
\text { - identification and systematization of information, its } \\
\text { storage; } \\
\text { - creation of databases; } \\
\text { - information support of training } \\
\text { forecasts of development of industries, enterprises of } \\
\text { the region; } \\
\text { - information support for risky projects; } \\
\text { - informational support of research works on problems } \\
\text { of development of socio-economic potential of the } \\
\text { region. }\end{array}$ & $\begin{array}{l}\text { - Identification, description of problems, trends, alternatives, conflicts and } \\
\text { emergencies; } \\
\text { - modeling of problems, choice of methods of their solution, estimation of } \\
\text { consequences; } \\
\text { - information and analytical review of plans, programs, results of examinations; } \\
\text { - analysis and forecasting of situations, problems in politics, economics, science, } \\
\text { production, business, etc .; } \\
\text { - minimization of risk factors; } \\
\text { - analytical evaluation of initiatives, innovations, development of proposals for } \\
\text { their use; } \\
\text { analysis of ratings, credit histories of objects; } \\
\text { - information support and analysis of socio-political actions and processes; } \\
\text { preparation of analytical and forecast materials. }\end{array}$ \\
\hline
\end{tabular}

Source: generated by the authors according to the study 
Inability to be exhausted. The provision of rural areas with natural attractions tends to be permanently restricted. Baits have an evolutionary property that is acquired over a long period of time. However, at the same time, people can influence the value of rural areas, which, above all, boils down to effective management and rational use, and as a result, to improving the well-being of rural residents;

\section{ל}

Irreversibility. In the process of ensuring human life, there is a growing need for the use of resources, and therefore maintaining or restoring the uniqueness of the territories has a high selling price. First of all, a person can influence processes that are inherently biomorphological (tree growth, wildlife production, steppe vegetation, etc.), rather than geomorphological (tectonic layers, volcanoes, soil structure, etc.), where the processes are very slow;

\section{Њ}

High elasticity of profit from demand. From a theoretical point of view, natural advantages guarantee a high elasticity of income from their use in relation to market demand. It is important that the preserved environment is the property of the rural society as a whole, and not only of private property, which in particular can significantly affect the loss of its sociocultural characteristics by the territory;

\section{Ђ}

Immobility. Natural lures exist as fixed assets of the region. First of all, they are the property of a separate territorial community, which independently makes a dichotomous choice in favor of promoting their own facilities in the external environment, or, conversely, limiting external access to them and using them to enhance their own potential.

Figure 2. Fundamental features of the uniqueness of rural areas

Source: generated by the authors according to the study

I $\rightarrow$ In-depth social development of infrastructure on the whole;

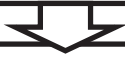

II $\rightarrow$ economic incentives for the work of small, especially farmers, flower-growing, horticultural and livestock farming enterprises;

III $\rightarrow$ organization on the modern technological basis of a system of local processing and marketing structures, consulting, laboratory and monitoring system by type of machine-tractor stations, rolling stations, maintenance stations, etc .;

$\mathbf{I V} \rightarrow$ development of the system of training (rural schools) and retraining of
qualification of agricultural workers in new conditions;
$\mathbf{V} \rightarrow$ state order for provision of low-skilled rural unemployed of different age
groups of land protection, creation of afforestation on degraded and
unproductive lands;

Figure 3. Main measures for social adaptation of rural areas

Source: generated by the authors according to the study 
Vol. 5, No. 5, 2019

Table 3

Factors of competitiveness of the region depending on the needs of target groups of consumers (markets)

\begin{tabular}{|c|c|}
\hline Consumer groups & Factors of competitiveness of the region \\
\hline People & $\begin{array}{l}\text { - political and social stability; crime rate; } \\
\text { - level of environmental pollution; infrastructure security; } \\
\text { - high level of production and consumption of gross regional product per capita; } \\
\text { - effective organization of space; } \\
\text { - intellectual, creative and cultural potential of the population of the territory; } \\
\text { - cozy and comfortable atmosphere on the territory; } \\
\text { - developed institutional environment; quality of life of the population. }\end{array}$ \\
\hline New Residents & $\begin{array}{l}\text { - positive image of the region; cleanliness and safety of the environment; } \\
\text { - developed labor market; high level of income and employment; } \\
\text { - migrant adaptation programs; } \\
\text { - rehabilitation of the homeless and other persons in difficult situations; } \\
\text { - cozy and comfortable atmosphere on the territory; } \\
\text { - profile of the region (structure of the economic complex of the territory, reflecting its functional specification); } \\
\text { level of life quality. }\end{array}$ \\
\hline $\begin{array}{l}\text { Manufacturers of goods } \\
\text { and services }\end{array}$ & $\begin{array}{l}\text { - local business climate; proximity to consumers and suppliers; } \\
\text { - availability and price of basic resources and finances; } \\
\text { - labor force (availability, qualification structure, cost, business reputation, reliability); } \\
\text { - production facilities (availability, cost); } \\
\text { - high domestic market capacity; favorable business climate; } \\
\text { - integration with local clusters; High life quality for the population. }\end{array}$ \\
\hline Investors & $\begin{array}{l}\text { - positive image and prestige of the region; } \\
\text { - geopolitical situation, natural-climatic and resource potential of the region; } \\
\text { - production and financial potential of the region and the state of its commodity markets; } \\
\text { - the level of market infrastructure development; level of development of innovative activity; } \\
\text { - qualification level of labor resources; life quality. }\end{array}$ \\
\hline Tourists & $\begin{array}{l}\text { - convenient geographical location; } \\
\text { - unique tourist resources; developed hotel infrastructure; } \\
\text { - availability of facilities and exposition areas; positive image of the territory; } \\
\text { - attractiveness of the environment and favorable natural and climatic conditions; } \\
\text { - developed and accessible system of communications and transport; } \\
\text { - developed industry of hospitality and entertainment (availability of areas for culture and recreation, } \\
\text { comfortable hotels and motels; cafes and restaurants); } \\
\text { - availability of unique monuments of architecture, culture, history; } \\
\text { - the life quality of the population. }\end{array}$ \\
\hline $\begin{array}{c}\text { Authorities of different } \\
\text { levels }\end{array}$ & $\begin{array}{l}\text { - positive image and prestige of the region; strategic geopolitical position; } \\
\text { - rich natural resource potential; availability of high-tech production; } \\
\text { - connected relationships and partnerships with other regions domestically and internationally; } \\
\text { - high evaluation of the effectiveness of the authorities; } \\
\text { - transparency of the information and institutional environment; } \\
\text { - high life quality of the population. }\end{array}$ \\
\hline
\end{tabular}

Source: generated by the authors according to the study

target consumer group can be divided into common and private (Hazuda, Erfan, Hazuda, 2015; Zhalilo, Shevchenko, Romanova, 2019). Common factors include the high level of life quality of the population, because of its importance and priority for all consumers. It follows that the life quality is a major competitive advantage of any rural area (Table 3 ).

\section{Indicators of economic status of rural development}

The economic status of rural territories (regions) is the aggregate of economic results obtained by the population, institutions located in the territory, over a certain period (year). In analyzing the economic situation and development of regions, such indicator as the gross regional product per capita or unit of labor is widely used (Hazuda, Erfan, Hazuda, 2015; Honcharuk, Tomashuk, 2018). The main partial indicators of the economic status of rural territories (regions) are proposed to use: monetary income per capita, UAH; share of employed population in total,\%; production of goods and services per capita, UAH; retail turnover per capita, UAH; commissioning of housing stock per capita, sq. $\mathrm{m}$. of the total area; volume of investments in housing construction per capita, UAH; volume of investments in fixed assets of enterprises per capita, UAH. and other.

In addition, the assessment of the uniformity of economic development of rural areas in Ukraine is 
proposed to be carried out by four complex criteria: the rate of economic growth in each region; economic growth in the region to the average in Ukraine; economic growth relative to the maximum achieved in the regions of Ukraine; uniformity of economic development (Hazuda, Erfan, \& Hazuda, 2015; Kaletnik, \& Pryshliak, 2010).

Particular attention should be paid to the issue of state regulation of environmental safety of rural development. Environmental safety is based on the observance of the basic components: the realization that humanity is an integral part of nature, completely dependent on its environment; recognizing the limited and finite nature of the natural resource (ecological) potential of the Earth and its individual regions, the need for its qualitative and quantitativeinventory; impossibility ofartificial expansion of natural resource (ecological) potential beyond natural system constraints; determining the maximum allowable for the extraction of natural resources and changing ecosystems as a living environment; the need to develop preventive environmental bans long before the economic depletion of natural resources or their indirect destruction; the obligation to create a socio-economic mechanism of homeostasis in the system «man - nature» type, i.e. «nature - commodity - money - nature» (similar to the mechanism «commodity - money - commodity»); the need to regulate the number of people, their pressure on the environment at local, regional and global levels; the acceptability of only «green» technologies and techniques in all sectors of the economy; the transition to resource-efficient technologies and miniaturization of products, to safe for nature and people economic receptions; recognition of the law of optimality, and in management - the principle of reasonable sufficiency in the use of ways of obtaining vital goods in spatial and temporal specific frameworks (restrictions on environmental, social and economic risk factors) (Hazuda, Erfan, Hazuda, 2015, Chuhunov, Pavelko, Kanieva, Mazaraki, 2015); understanding that without an adequate environment (ecosystem integrity) it is impossible to preserve anything alive, including its species (including humans) and the natural systems of the lower level of the hierarchy.

\section{Current state of functioning of rural territories}

The present state of functioning of rural territories is reduced to providing the population with foodstuffs, and industry with agricultural raw materials, however, according to A. Pavlov (Pavlov, 2019), they are able to perform several functions at the same time, which corresponds to their nature as a complex socio-spatial formation. According to the fact that rural areas play a decisive role in life support (food production), livelihoods (living conditions and life quality of rural population), nature management (environmental development) (Hazuda, Erfan, Hazuda, 2015; Mazur,
Kostiuk, 2018), it is possible to distinguish industrialeconomic, health-recreational, environmental and social functions, the effectiveness of which will contribute to the sustainable development of society.

In this context, the modern process of formation of united territorial communities, which can be called dynamic, deserves special attention: as of 2015, 159 united territorial communities were formed in Ukraine; as of 2016 there were 366; as of 2017 there were 665; and as of March 2019, there were already 884 united communities (Zhalilo, Shevchenko, Romanova, 2019). In addition, it should be emphasized that one of the fundamental principles of a democratic society is the involvement of public in the decision-making process. Therefore, an important component of the new stage of decentralization reform will be the drafting and tabling of draft laws on effective mechanisms for public participation in political life in the country (Zhalilo, Shevchenko, Romanova, 2019; Zaiats, 2017). Studies also confirm the importance and actualization of rural development, which is clearly traced through the basic functions of rural territories based on the generalization of scientific approaches (Figure 4).

In this context it should be emphasized the interdependence of the development of rural areas multifunctionality of agriculture, which is that its result is the production not only of food, raw materials for food and processing industry, and energy raw materials more recently, but also a number of important public goods, for which demand is growing in the modern world. Rural areas are the basis of these benefits (externalities arising from agricultural production) which include (Hazuda, Erfan, Hazuda, 2015, Zinchuk, Kutsmus, 2012): food security of the country, which is seen as free physical and economic access of all population to safe food in sufficient quantity to meet their needs and preferences in the volumes necessary for a healthy, active life; the impact on the environment (formation and protection of agricultural lands, agrobiological diversity, maintenance of soil fertility, protection of land from negative effects of natural and technogenic character); the maintenance of population in rural areas through the use of their natural resources for economic activity that provides the means to meet the physical, spiritual and social needs (Bobrovska, 2014, Hazuda, Erfan, Hazuda, 2015); the reproduction and development of the peasantry (farming) as the bearer of national identity, grain culture and spirituality.

\section{Factors influencing the effective development of rural areas and their economic evaluation}

The most appropriate for understanding and identifying the interdependencies of the factors influencing rural development, in our opinion, is the law of unity and the struggle of opposites, which 


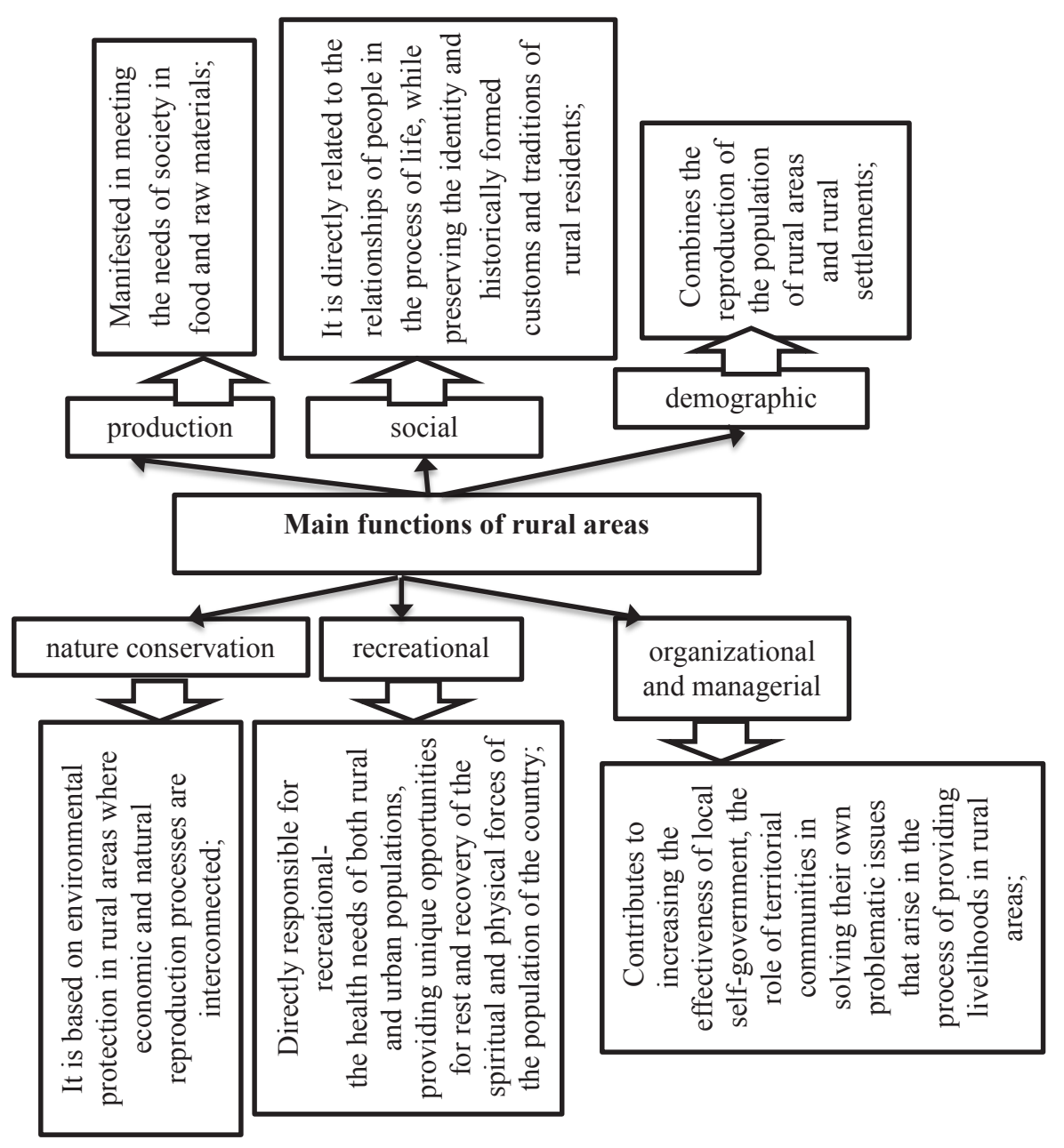

Figure 4. Main functions of rural areas

Source: generated by the authors according to the study

indicates the source of movement, development of objects, processes and phenomena. In accordance with this law, the most important condition that gives rise to development is a dialectical contradiction characterized by specific forms of this process (Figure 5) (Bobrovska, 2014; Hazuda, Erfan, \& Hazuda, 2015).

Local economic development is an activity of enterprises, economic entities in the region, authorities

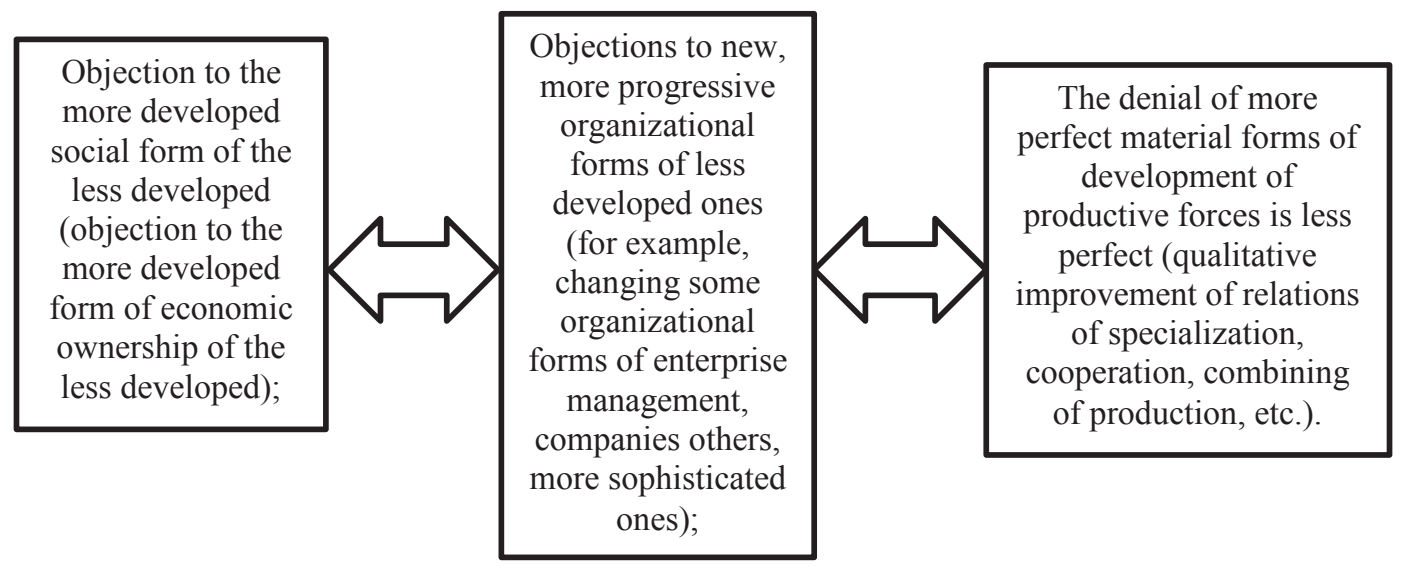

Figure 5. Forms of interdependence of factors of influence on rural development

Source: generated by the authors according to the study 
operation of enterprises located in a certain territory, including in the context of the natural-economic zones of the region;

availability of industrial and social infrastructure, which greatly contributes to the economic growth of the countryside and the effective functioning of the social sphere;

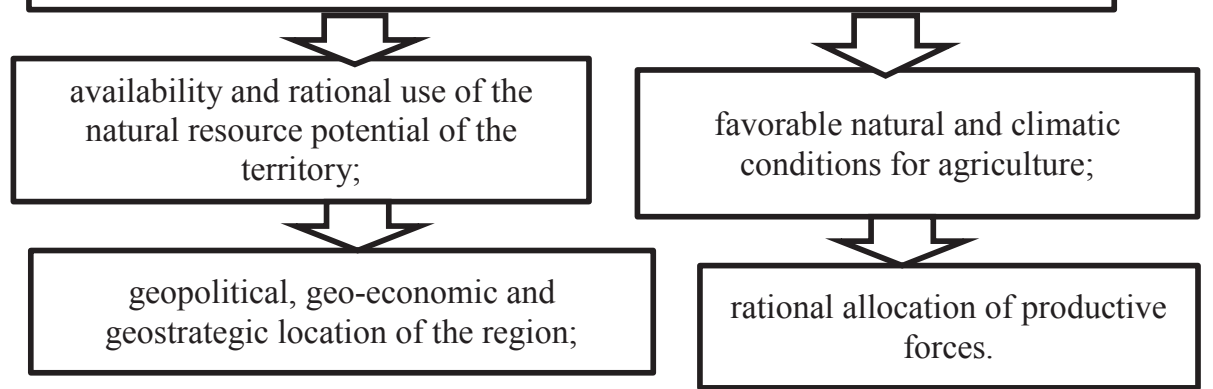

Figure 6. Features of economic assessment of rural development

Source: generated by the authors according to the study

and other interested parties, aimed at increasing the economic resources of the community and obtaining a positive socio-economic effect (Honcharuk, Tomashuk, 2018). Stable local economic development provides employment opportunities for economically active population in the region, is a basis for improving the well-being of local residents, contributes to improving the quality of life throughout the country. The economic assessment of rural development has its own specific features, since it should include the level of development of rural territories as a whole (Figure 6) (Hazuda, Erfan, Hazuda, 2015, Kaletnik, Pryshliak, 2010).

\section{Impact of agricultural production on the efficiency of rural areas}

The practice of agricultural management has shown that the management efficiency of the agro-industrial complex depends to a large extent on the availability of timely and high-quality information support. Monitoring plays a special role in this process. Monitoring (from the Latin "monitor" is reminiscent of "the monitor") is defined in the scientific literature as a specially organized systematic observation of a specific object (Bobrovska, 2014; Hazuda, Erfan, \& Hazuda, 2015).

Monitoring any development is the process of providing the management system with information about the compliance of the entity's performance with the selected criteria. Quality monitoring organization of rural capacity development involves observing the factors and trends of development of objects in order to inform the support of operational and strategic decisions, establishing the level of adaptation of the object to the environment, etc.

One of the main tools for identifying priority development areas and strategic management, evaluating the complex internal and external factors that affect the development of the territory, is the SWOT analysis. SWOT initial letters of the words Strengths, Weaknesses, Opportunities, Threats. SWOT analysis is

Table 4

Impact factors and risks of rural development based on agricultural production

\begin{tabular}{|c|c|c|c|}
\hline & Positive prerequisites & Risks & Precautions \\
\hline 1. & Favorable geographical location & Customs procedures & $\begin{array}{c}\text { Creation of green corridors, development } \\
\text { of transport networks }\end{array}$ \\
\hline 2. & Moderate continental climate & Drought & Reclamation systems, greenhouses \\
\hline 3. & Fertile soils & Exhaustion & Agrotechnology \\
\hline 4. & $\begin{array}{l}\text { A large proportion of the rural population } \\
\text { is engaged in traditional farming }\end{array}$ & Labor migration & Support programs for single farms \\
\hline 5. & $\begin{array}{c}\text { Growing a wide range of agricultural } \\
\text { products }\end{array}$ & $\begin{array}{l}\text { Market oversaturation with monotonous } \\
\text { products }\end{array}$ & Pre-orders, cooperation manufacturers \\
\hline 6. & The possibility of harvesting two crops & $\begin{array}{l}\text { Violation of permissible standards for the } \\
\text { use of mineral fertilizers }\end{array}$ & Product quality control system \\
\hline 7. & Sales of products from the field & Illiquid balances & Serving cooperative, logistics \\
\hline
\end{tabular}

Source: generated by the authors according to the study 
a kind of tool; it does not contain final information for managerial decision-making, but allows streamlining the process of consideration of all available information with their own thoughts and evaluations (Hazuda, Erfan, Hazuda, 2015). Implementation of the SWOT analysis helps to establish relations between the characteristic of regional (rural) development opportunities, threats, strengths (advantages) and disadvantages. As the result of this analysis, it is possible to identify promising directions and to carry out the choice of strategies for rural development (Table 4).

World experience shows that the successful functioning of the market of agricultural products in rural areas provides marketing planning.

For the effective development of rural areas it is expedient to establish an agricultural service cooperative, which will carry out the procurement, storage and preprocessing, and the sale of the product, its transportation and marketing services that will reduce risks and costs for both manufacturer and processor of agricultural products and establish cooperation with dockworkers and retailers. After all, the main vocation of the rural environment is the production of agricultural products, providing the population with food and processing industry with raw materials.

\section{Sustainable economic growth of rural territories of Ukraine in the light of world experience}

The main task of the present and the following years is to implement a policy of sustainable economic growth and improving the living standards of the rural population (Bobrovska, 2014; Honcharuk, Tomashuk, 2018). World science and practice have accumulated considerable experience in researching sustainable rural development. At the same time, funding for activities of the so-called «green box» containing some types of internal support is increasing (Table 5).

Support for rural development is a further priority of EU policy, driven by the new 2014-2020 programming period. EU rural development priorities have been expanded (four-axis system replaced by six priorities), in particular (Figure 7) (Hazuda, Erfan, Hazuda, 2015, Honcharuk, Tomashuk, 2018).

Summarizing the above, it is possible to outline the basic principles and directions of using international experience in regulating rural development in Ukraine (Table 6).

\section{Impact of government levers on rural development}

At present, it is important to understand by the state and governmental structures that rural development is a major component of both the economic and national security of the country as a whole, and therefore its support will contribute to ensuring a balanced socioeconomic and environmental development of rural areas. In this context, decentralization is one way to tackle rural poverty (Bobrovska, 2014; Hazuda, Erfan, \& Hazuda, 2015).

In the system of state regulation of rural development, an important role belongs to regional programs of socioeconomic and environmental development, their essence lies in a comprehensive approach to solving the main

Table 5

The main components of sustainable rural development

\begin{tabular}{|c|l|}
\hline I & $\begin{array}{l}\text { General services such as research funding, pest and disease control, specialist training and retraining, inspection, marketing services } \\
\text { and infrastructure support; }\end{array}$ \\
\hline II & $\begin{array}{l}\text { Direct payments to producers: income support, not «tied» to production results, income insurance for social programs, payments } \\
\text { to producers for losses from crop and animal diseases, retirement programs or for withdrawal of production resources, investment } \\
\text { assistance, environmental programs and regional support programs; }\end{array}$ \\
\hline III & Maintaining food security stocks; \\
\hline IV & Domestic food assistance. \\
\hline
\end{tabular}

Source: generated by the authors according to the study

\begin{tabular}{|c|c|c|c|c|c|c|}
\hline & I & II & III & IV & $\mathbf{V}$ & VI \\
\hline 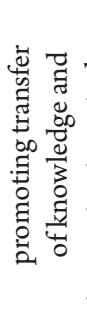 & 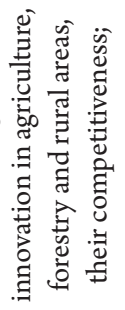 & 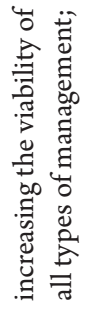 & 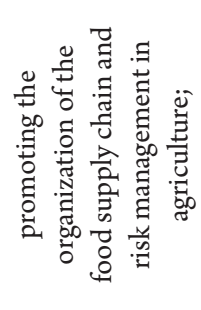 & 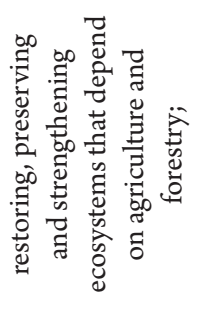 & 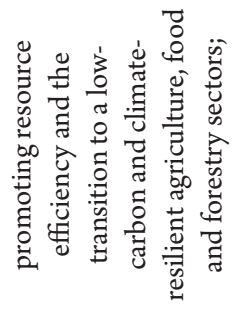 & 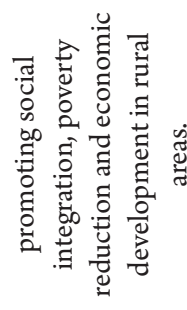 \\
\hline
\end{tabular}

Figure 7. EU rural development priorities

Source: generated by the authors according to the study 
Table 6

Main principles and directions of regulation of rural development of Ukraine taking into account EU experience

\begin{tabular}{|c|c|}
\hline & Characteristic \\
\hline 1 & legislative support and implementation of the adopted and existing legislative acts on rural development is important; \\
\hline 2 & provision of targeted state funding for rural development programs, financing of rural development on a competitive basis; \\
\hline 3 & expansion of bank lending to rural business entities, development of investments in priority sectors in rural areas; \\
\hline 4 & selective financing of prospective investment projects, in particular in the development of rural infrastructure; \\
\hline 5 & $\begin{array}{l}\text { stimulating the development of entrepreneurship, the creation of small forms of farming in the agricultural sector } \\
\text { and small enterprises in the industries; }\end{array}$ \\
\hline 6 & stimulating the development of organic farming; \\
\hline 7 & development of tourist and recreational infrastructure; \\
\hline 8 & ordering of roads, development of road infrastructure; \\
\hline 9 & $\begin{array}{l}\text { enhancing the status of mountain areas (legislative and financial support) and in particular: } \\
\text { - investment assistance to mountain areas, granting loans on preferential terms; } \\
\text { - creation of a network of small and medium enterprises in the mountains for the production of high-quality goods and services; } \\
\text { - expansion of productive meadows and pastures in the structure of agricultural lands of the mountainous terrain, } \\
\text { development of animal husbandry in the mountains, especially sheep farming; } \\
\text { - stimulating the development of rural green tourism; }\end{array}$ \\
\hline 10 & solving problems of employment of rural population; \\
\hline 11 & enhancing self-government and enhancing the role of the community in managing rural development; \\
\hline 12 & ensuring systematic monitoring of the implementation of investment projects and rural development programs. \\
\hline
\end{tabular}

Source: generated by the authors according to the study

goals and objectives of ensuring a balanced development of the rural environment, namely: ensuring a balanced socio-economic development of the region, in particular the countryside; attraction of investments to priority types of economic activity through creation of special economic zones, joint ventures, etc.; improvement of the structure of the economic complex by conversion, reorientation of certain enterprises of the machinebuilding industry to the production of acute-scarce agricultural machinery and equipment, durable goods for the population, etc.; promotion of rational use of the region's resources (natural, material, labor, financial and others); environmental protection in the region; improving demographics and more; a gradual increase in the standard of living of the region's population as a result of fulfilling these goals and objectives (Hazuda, Erfan, \& Hazuda, 2015; Pavlov, 2019).

Regional programs are short-term (up to 1 year), medium-term ( 1 to 5 years) and long-term (over 5 years) periods.

In the process of ensuring the development of rural living environment, regulatory documents with changes and additions that promote the development of individual housing construction in the countryside, the expansion of water, gas, heat supply networks and others are important. In particular, resolutions of the Cabinet of Ministers of Ukraine $\ll$ On measures to support individual housing construction in the countryside», «On water supply to rural settlements of Ukraine», «On gasification of rural settlements and increase of electricity use for rural household needs , «On improvement of investment formation in rural areas, social development of the village and agro-industrial complex» and others.
The analysis of conditions of financial resources formation of agricultural enterprises that operate in rural areas and access to external sources of financing demonstrates the need for review of the conceptual bases of state regulation of the economy and enhance the position of the state (Kaletnik, Pryshliak, 2010).

The current situation in Ukraine requires new approaches to the implementation of reforms and policy to support rural development. The integrated development strategy of agriculture and rural development 2015-2020 aims to meet this challenge and to comprehensively implement a number of reforms that have been waiting for agricultural producers, agribusiness and the rural population (Smutchak, 2019). The development of scientific and practical management approaches to ensure the competitiveness of food production, especially by growing organic, highquality and safe agricultural products, the demand for which is growing, in particular and in the world is noted among the prority tasks of regional management.

\section{Main aspects of solving economic problems of rural development}

The rural development is a difficult task. This is reflected in the complexity of the problem, the multiplicity of solutions, the diversity of interests of the subjects. One of the ways to solve it is the introduction of an effective economic mechanism to support the development of rural areas, which are characterized by some aspects to solve this problem (Figure 8).

Modern-oriented model of forming of the motivational factors of the development potential 
$\rightarrow$ The need to create conditions for rural development, effective functioning of the market mechanism in rural areas (level of profitability of agriculture, land commodity);

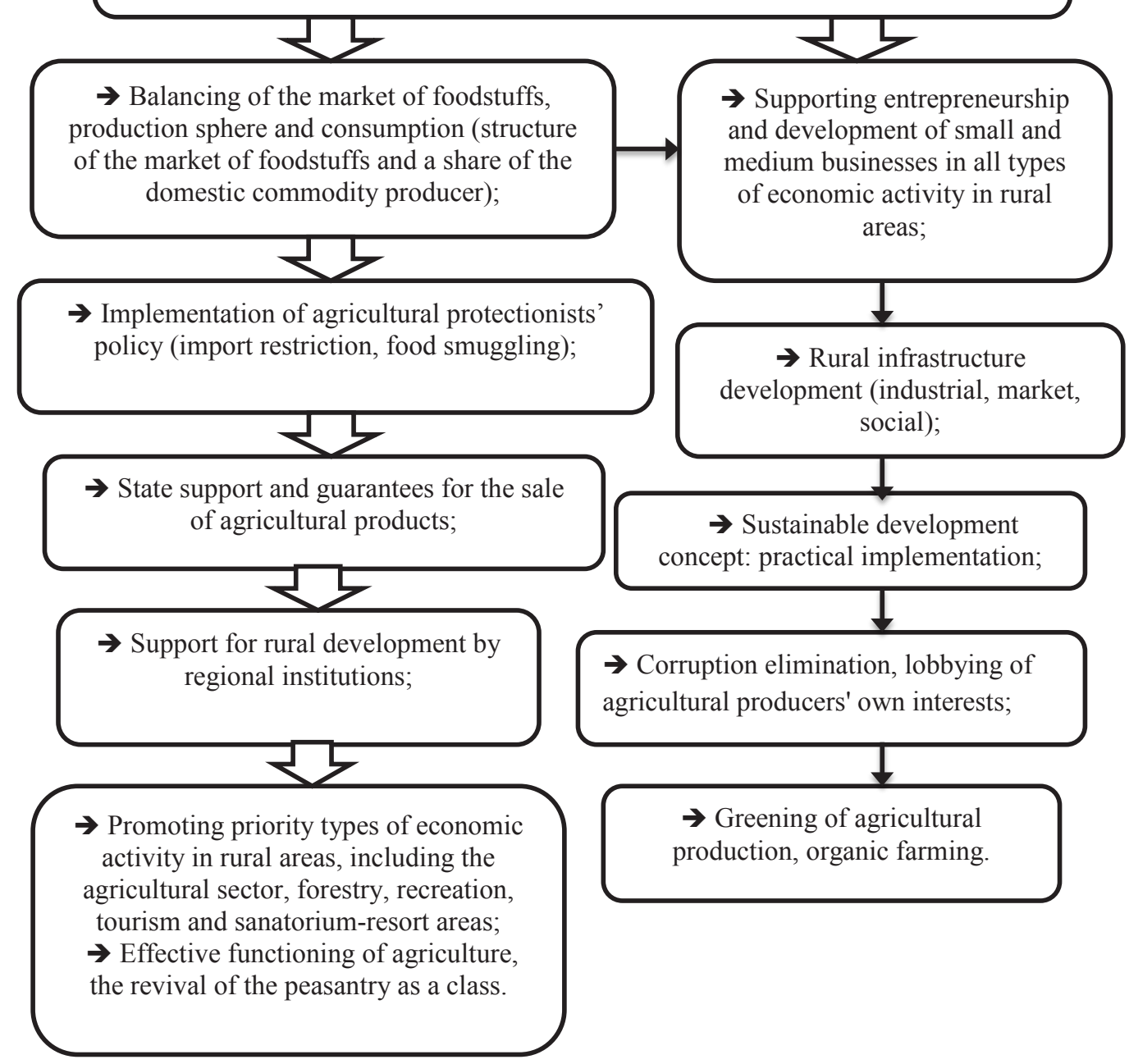

Figure 8. Main aspects of solving economic problems of rural development

Source: generated by the authors according to the study

of rural areas provided that its implementation will involve the strengthening of the role of the state in the continuation and completion of effective reforms in the countryside. This is possible through the use of motivational factors that will provide impetus to the tasks of socio-economic development of rural areas. There is also implied a high responsibility of the executive authorities and local self-government bodies on implementation of tasks set out in national and regional policy frameworks development of rural areas to enforce the constitutional rights of man and citizen and the development of local democracy and to promote healthy competitiveness and human development. In addition, to create conditions for ensuring the effectiveness of functioning of industrial enterprises and enterprises of the agrarian sector and to provide vital needs and interests of the rural population.

\section{Conclusions}

Implementation of the tasks of effective development of rural territories at the expense of state support will contribute to the improvement of rural settlements, increase of income, increase of the level and quality of life of rural residents. In the context of the implementation of rural development tasks, the role of territorial communities in the consideration and resolution of economic and socio-cultural issues of local importance, including the protection of the environment of rural territories, is increasing.

The economic policy of rural territories should be based not on the modifications of managerial influence, but on the construction of an economic institute of their own systemic structural and economic shifts, opportunities to use their own potential. The prospect of further development is extremely important to conduct regional diagnostics at the state level, which will include 
assessing the level of development of the region, its specialization and the complexity of the development of productive forces, their effectiveness, as well as the study of regional markets for goods and services, labor, financial structures, levels of investment and innovation.
The analysis of population characteristics (demographic indicators, settlement systems, etc.), assessment of natural resource, scientific and production potentials, the level of development and location of infrastructure, environmental security are also important.

\section{References:}

Bobrovska, O. Yu. (2014). Realizatsiia Derzhavnoi stratehii rehionalnoho rozvytku na period do 2020 roku: materialy konferentsii [Implementation of the State Regional Development Strategy for the period up to 2020]. Dnipropetrovsk: NADU, 324 p. (in Ukrainian)

Hazuda, L. M., Erfan, V. Y., \& Hazuda, S. M. (2015). Silskyi rozvytok rehionu: monohrafiia [Rural development of the region: a monograph]. Uzhhorod: Vydavnytstvo FOP Sabov A.M., 250 p. (in Ukrainian)

Holovne upravlinnia statystyky u Vinnytskii oblasti (2019). [Main Department of Statistics in Vinnytsia Oblast]. Retrieved from: http://www.vn.ukrstat.gov.ua/images/stories/Exspres/2019/09/19.09.19indecs.pdf (accessed 09 September 2019).

Honcharuk, I. V., \& Tomashuk, I. V. (2018). Derzhavne rehuliuvannia rozvytku resursnoho potentsialu silskykh terytorii: zahalni aspekty [State regulation of rural potential resource development: general aspects]. Ekonomika. Finansy. Menedzhment: aktualni pytannia nauky i praktyky, 4(32), 19-30. (in Ukrainian)

Zhalilo, Ya. A., Shevchenko, O. V., \& Romanova, V. V. (2019). Detsentralizatsiia vlady: poriadok dennyi na serednostrokovu perspektyvu. Analitychna dopovid [Decentralization of power: an agenda for the medium term. Analytical report]. Natsionalnyi instytut stratehichnykh doslidzhen. Kyiv, 115 p. (in Ukrainian)

Zaiats, T. A. (2017). Transformatsiia silskoho rozselennia v Ukraini: kol. monohr. [Transformation of rural settlement in Ukraine]. Instytut demohrafii ta sotsialnykh doslidzhen im. M.V. Ptukhy NAAN Ukrainy. Kyiv, 298 p. (in Ukrainian)

Zinchuk, T. O., \& Kutsmus, N. M. (2012). Prynady silskykh terytorii: novyi teoretyko-metodolohichnyi pidkhid chy zabuta potreba silskoho rozvytku? [Rural charms: a new theoretical and methodological approach or a forgotten need for rural development?]. Stalyi rozvytok ekonomiky, 1(11), 155-161. (in Ukrainian)

Kaletnik, H. M., \& Pryshliak, N. V. (2010). Derzhavna finansova pidtrymka silskohospodarskykh tovarovyrobnykiv [State financial support for agricultural producers]. Ekonomika APK, 8, 52-55. (in Ukrainian)

Mazur, K. V., \& Kostiuk, V. I. (2018). Upravlinnia zemelnymy resursamy v umovakh detsentralizatsii [Land management under decentralization]. Molodyi vchenyi, 4(2), 806-809. (in Ukrainian)

Pavlov, O. I. (2019). Silski terytorii: teoretyko-metodolohichni zasady doslidzhennia [Rural areas: theoretical and methodological foundations of the study]. Retrieved from: http://history.org.ua/JournALL/regions/3/5.pdf (accessed 27 August 2019).

Smutchak, Z. V. (2019). Rol derzhavnoho upravlinnia u stalomu rozvytku silskykh terytorii Ukrainy [The role of public administration in the sustainable development of rural areas of Ukraine]. Retrieved from: http://economyandsociety.in.ua/journal/10_ukr/82.pdf (accessed 05 August 2019).

Chuhunov, I. Ia., Pavelko, A. V., Kanieva, T. V., \& Mazaraki, A. A. (2015). Derzhavne finansove rehuliuvannia ekonomichnykh peretvoren: monohrafiia [State financial regulation of economic transformations: a monograph]. Kyiv. nats. torh.-ekon. un-t, 376 p. (in Ukrainian) 